УДК 342.951

DOI: https://doi.org/10.54929/pmtl-issue1-2021-08

\title{
ДОКТРИНА ІНФОРМАЦІЙНИХ ПРАВОВІДНОСИН В УМОВАХ ДЕРЖАВНОЇ ПОЛІТИКИ ПЕРЕХІДНОГО ПЕРІОДУ В УКРАЇНІ
}

\author{
THE DOCTRINE OF INFORMATIONAL LEGAL RELATIONS \\ IN THE CONDITIONS OF THE STATE POLICY OF TRANSITION \\ IN THE UKRAINE
}

Філатов В. В.

кандидат юридичних наук, доцент, доцент кафедри цивільного, господарського та екологічного права Університет митної справи та фрінансів, Дніпро ORCID: https://orcid.org/0000-0002-8059-3736

Filatov V. V.

Candidate of Legal Sciences, Associate Professor Associate Professor of the Department of Civil, Commercial and Environmental Law, University of Customs and Finance

У статті досліджується проблема впливу політики перехідного періоду в Україні на процес розвитку доктрини інфрормаційних правовідносин. Розглянуто основні принципи та напрямки перехідного правосуддя, схарактеризовано фрорми та методи їхньої реалізації. Детально проаналізовано стан розвитку доктрини інформаційних правовідносин в Україні. Запропоновано перспективні тенденції розвитку доктрини інформаційних правовідносин в умовах перехідного правосуддя. Автором встановлено, що трансорормація інфоормаційного законодавства обумовлює необхідність перегляду об'єктного та суб'єктного складу інформаційних правовідносин. В цій статті обгрунтовано наступні перспективні напрямки розвитку доктрини інфрормаційних правовідносин в умовах політики перехідного періоду: узагальнення уявлень про систему суб'єктів інформаційних правовідносин; розвиток доктрини об'єктів інформаційних правовідносин; удосконалення теоретичних положень щодо змісту інформаційних правовідносин. Ключові слова: інфрормаційні правовідносини, законодавство, принципи та напрямки, політика перехідного періоду, розвиток та трансформація, фоорми та методи.

В статье исследуется проблема влияния политики переходного периода в Украине на процесс развития доктрины информационных правоотношений. Рассмотрены основные принципы и направления переходного правосудия, охарактеризованы формы и методы их реализации. Детально проанализировано состояние развития теории инсормационных правоотношений в Украине. Предложены перспективные тенденции развития теории информационных правоотношений в условиях переходного правосудия. Автором установлено, что трансформация информационного законодательства обусловливает необходимость пересмотра объектного и субъектного состава инфрормационных правоотношений. В этой статье обоснованы следующие перспективные направления развития доктрины инфрормационных правоотношений в условиях политики переходного периода: обобщение представлений о системе субъектов информационных правоотношений; развитие теории объектов информационных правоотношений; совершенствование теоретических положений относительно содержания информационных правоотношений. Ключевые слова: информационные правоотношения, законодательство, принципы и направления, политика переходного периода, развитие и трансформация, фрормы и методы.

The article examines the problem of the impact of transition policy in Ukraine on the development of the doctrine of information relations. The basic principles and directions of transitional justice are considered, the forms and methods of their realization are characterized. The state of development of the theory of information legal relations in Ukraine is analyzed in detail. Perspective tendencies of development of the theory of information legal relations in the conditions of transitional justice are offered. It is established that at the present stage of development of legal science information law, unfortunately, is only at the stage of formation. In this regard, there is a need for a comprehensive scientific understanding of certain categories of this area of legal knowledge. First of all, we are talking about the category of "information relations", the idea of which is quite general and not systematized. The development of the doctrine of information relations requires a scientific analysis not only of the basic elements (object, subject, content), but also a thorough understanding of the factors that today influence the process of their formation. These are external factors, the existence of which is due to the socio-political situation in the country. Areas of transitional justice significantly affect the legislation, practice of its application and implementation of institutional reforms in the state. In view of this, the problem of characterizing the influence of transitional justice in Ukraine on the process of formation and development of the theory of information relations is urgent. 
The purpose of the article is a comprehensive theoretical and legal analysis of the impact of transition policy on the development of the doctrine of information relations. The author found that the transformation of information legislation necessitates a revision of the object and subject composition of information relations. This article substantiates the following promising areas of development of the doctrine of information relations in the policy of transition: generalization of ideas about the system of subjects of information relations; development of the theory of objects of information legal relations; improvement of theoretical provisions on the content of information relations. Key words: information legal relations, legislation, principles and directions, policy of transition period, development and transformation, forms and methods.

Постановка проблеми у загальному вигляді та її зв'язок із важливими науковими та практичними завданнями. На сучасному етапі розвитку юридичної науки інформаційне право, на жаль, знаходиться лише на стадії становлення. У зв'язку з цим, існує необхідність комплексного наукового осмислення окремих категорій означеної галузі правових знань. Перш за все, мова йде про категорію «інформаційні правовідносини», уявлення про яку досить загальні та не систематизовані. Розвиток доктрини інфрормаційних правовідносин вимагає наукового аналізу не тільки основних елементів (об'єкт, суб'єкт, зміст), а й ґрунтовного осмислення тих чинників, які сьогодні впливають на процес їхнього становлення. Йдеться про сторонні чинники, існування яких обумовлене соціально-політичною ситуацією в державі.

Аналіз останніх досліджень і публікацій. У вітчизняній юридичній науці проблема впливу політики перехідного періоду на розвиток доктрини інформаційних правовідносин раніше не досліджувалася, що вказує на актуальність обраного напрямку наукового пошуку.

Виділення невирішених раніше частин загальної проблеми, котрим присвячується означена стаття. Напрямки перехідного правосуддя суттєво впливають на законодавство, практику його застосування та впровадження інституційних реформ в державі. 3 огляду на це, нагальною $€$ проблема характеристики впливу правосуддя перехідного періоду в Україні на процес становлення і розвитку доктрини інформаційних правовідносин.

Формулювання цілей статті (постановка завдання). Метою статті $€$ комплексний теоретико-правовий аналіз впливу політики перехідного періоду на процес розвитку доктрини інформаційних правовідносин.

Виклад основного матеріалу дослідження. Розвиток теорії права відбувається під впливом численних чинників соціально-політичного та економічного характеру. Одним з них, на сучасному етапі розвитку Української держави, є перехідне правосуддя. Як комплексна аналітична модель, правосуддя перехідного періоду суттєво впливає на державну політику, законодавство та практику його застосування. Це змушує юридичну науку переосмислювати окремі теоретичні положення, трансформувати праворозуміння окремих категорій, запроваджувати нові правові інститути. Не $є$ виключенням інформаційне право, розвиток якого обумовлений не тільки перехідним правосуддям, а й тотальною інформатизацією усіх сфрер життя суспільства.

Питання «правильного» опрацювання злочинів, успішних соціальних перетворень, а також шляхів встановлення тривалого миру та безпеки в пост-конфрліктних ситуаціях набули в 20 столітті значно більшої ваги. В цьому контексті відбулося формування терміну «правосуддя перехідного періоду», який з часом набув глобального значення. Концепція «правосуддя перехідного періоду» характеризується тим, що перехідний етап тісно пов'язаний з встановленням законності, яка розуміється не тільки як покарання за злочинну поведінку. Концепція несе в собі глибший зміст і демонструє, що мир та безпека можуть бути забезпечені тільки в тому разі, якщо минулі війни та порушення прав людини будуть повністю опрацьовані [1, с. 6].

Вбачається, що перехідне правосуддя застосовується у пост-конфрліктному та пост-авторитарному періодах, як інструмент налагодження нормального життя суспільства. Модель перехідного правосуддя складається з: ідеологічного, правового та управлінського аспектів, які деталізовані в окремих напрямках (інституційні рефрорми, констатація істини, реалізація компенсаційних заходів тощо) [2, с. 94]. Слід припустити, що перехідне правосуддя впливає на усі сфери суспільного життя, адже після «Революції гідності» відбулися кардинальні зміни у державній політиці. Перш за все, це стосується безпекового виміру, який зазнав напевно найбільших перетворень.

Зокрема, саме напрямками перехідного правосуддя обумовлено затвердження нової Доктрини інформаційної безпеки України, метою якої є уточнення засад формування та реалізації державної інформаційної політики, насамперед щодо протидії руйнівному інформаційному впливу Російської Федерації в умовах розв'язаної нею гібридної війни [3]. На нашу думку, це є проявом ідеологічного аспекта перехідного правосуддя, адже на нормативно-правовому рівні будо закріплено основоположні засади захисту інтересів держави, суспільства та особистості в інфрормаційній сфері.

Проявом правового аспекта перехідного правосуддя в інформаційній сфері $є$ удосконалення законодавчих засобів забезпечення прозорості та незалежності окремих суб'єктів інформаційних правовідносин, недопущення цензури. Наприклад, 
Законом України «Про реформування державних і комунальних друкованих засобів масової інфрормації» від 24 грудня 2015 року № 917-VIII передбачені наступні способи реформування: вихід органів державної влади, інших державних органів та органів місцевого самоврядування із складу засновників (співзасновників) друкованого засобу масової інформації та їхньої редакції; перетворення друкованих засобів масової інформації, заснованих центральними органами виконавчої влади, в офріційні друковані видання [4]. Вбачається, що модернізація інформаційного законодавства є передумовою розвитку доктрини інформаційних правовідносин, адже нові методи та фрорми потребують врахування при визначенні правового становища суб'єктів.

Управлінський аспект перехідного правосуддя відбивається на інформаційній сфрері шляхом організаційно-розпорядчих змін, які спрямовані на законність та дисципліну в означеній сфері. Так. у 2014 році створено Міністерство інформаційної політики України, завданням якого є забезпечення інформаційного суверенітету України, створення умов для нормального функціонування державних інформаційних ресурсів, реформування сфрери ЗМІ (Постанова Кабінету Міністрів України «Про затвердження Положення про Міністерство інформаційної політики України» від 14 січня 2015 року № 2) [5]. Такі організаційні зміни впливають на зміст інформаційних правовідносин, адже окремі суб'єкти отримують нові права та обов'язки. До того ж, відбувається розширення об'єктного складу за рахунок уведення нових категорій (інформаційні інтереси держави, інформаційні ресурси та інше).

3 приводу розвитку доктрини інформаційних правовідносин в Україні окремі науковці наголошують на різних перспективах. Як зазначає Л. П. Коваленко, розвиток доктрини інфоомаційних правовідносин ґрунтується на принциповому розмежуванні типів останніх (інфооммаційні відносини безпосередньо пов'язані з формуванням, створенням, перетворенням та використанням інформації, зберіганням інформації, передачею і розповсюдженням інформації та ін) [6]. Вважаємо, що розподіл безумовно має значення, але більш пріоритетним $€$ змістовне наповнення категорії «інформаційні правовідносини», зокрема і за рахунок визначення чинників, що впливають на їхній розвиток.

У цьому сенсі більш слушною є думка Д. Ю. Шпенова, який стверджує, що подальший розвиток інформаційних правових відносин має бути спрямований на розробку програм розвитку інформаційної сфери, що містять основні напрями розвитку і шляхи побудови правового інфрормаційного суспільства, забезпечення функціонування інфрормаційної сфрери як правового простору, на- лагодження системного та масового виробництва національного інформаційного, подолання технологічного відставання у сфері інформаційно-телекомунікаційних технологій, ліквідація комп'ютерної неосвіченості та інтенсифікації впровадження Інтернет-сервісів у різні ссрери суспільного життя $[7$, c. 897]. Можна зазначити, що науковець вказує на залежність доктрини інфрормаційних правовідносин від суспільно-політичних чинників, яким, по суті, $є$ перехідне правосуддя.

Таким чином вплив перехідного правосуддя на інфрормаційні правовідносини проявляється у наступному: відбувається трансформація інфрормаційного законодавства, яка обумовлює необхідність перегляду об'єктного та суб'єктного складу. Мається на увазі не тільки розширення кола учасників, а й запровадження нових об'єктів, з приводу яких і виникає інтерес суб'єктів правовідносин; фрормуються нові напрямки діяльності органів влади та місцевого самоврядування, внаслідок чого виникає потреба вписати їх у вже існуючу доктрину інформаційних правовідносин. Йдеться про питання компетенційного, функціонального та ідеологічного значення; здійснюється перегляд змісту інформаційних правовідносин. При чому мова йде не тільки про впровадження нових прав та обов'язків. Слід враховувати і розширення кола юридичних фактів, за наявності яких виникають, змінюються та припиняються інформаційні правовідносини; перехідне правосуддя впливає на методологію правового регулювання інформаційних правовідносин. У даному випадку, право одночасно виступає у якості напрямку та засобу трансформації правозастосовчої та правоохоронної сфери. Це неодмінно позначається на доктрині інформаційних правовідносин, яка не може існувати ізольовано від відповідної сфери правового регулювання; принципи перехідного правосуддя обумовлюють необхідність переосмислення засад регулювання інформаційної сфери. На перший план виходить принцип констатації істини, тобто чіткого окреслення існуючих та потенційних загроз.

3 огляду на вищенаведене, доцільно запропонувати наступні перспективні напрямки розвитку доктрини інформаційних правовідносин:

1. Узагальнення уявлень про систему суб'єктів інформаційних правовідносин, зокрема тих, які з'явилися останнім часом. Мова йде не тільки про їхню класифрікацію, а й чітке розмежування обсягу та особливостей правового статусу. Потреба у такому узагальненні обумовлена не тільки перехідним правосуддям, але й науково-технічним прогресом в цілому. 3 цього приводу А. І. Марущак зазначає, що спочатку до інфрормаційних потоків у якості суб'єктів входили сім'ї, роди, племена, які передавали власний досвід із покоління у покоління. Пізніше до суб'єктного складу інформаційних відносин почали входити держави, юридичні осо- 
би приватного і публічного права. Ми, можливо, на сьогодні перебуваємо напередодні виникнення нових учасників інформаційних відносин, якими зможуть стати новітні інформаційні технології, наділені штучним інтелектом [8, с. 44]. Ще одним актуальним питанням $€$ аналіз обсягу правосуб'єктності учасників інформаційних правовідносин, зокрема на предмет відповідності Конституції та законам України. Тому цей напрям без перебільшень можна назвати перспективним.

2. Розвиток теорії об'єктів інформаційних правовідносин. Зокрема, виникає потреба детального наукового осмислення нових об'єктів, виникнення яких зумовлено інформатизацією суспільства. Одним із числа таких об'єктів є інформаційні ресурси, як організована і структурована документована інформація (знання, відомості), яка міститься в бібліотеках, архівах, фондах, банках даних, інформаційних системах. Правова природа інфрормаційних ресурсів як об'єкта інформаційних правовідносин $є$ різнобічною, і це повинно враховуватися під час розроблення конкретних організаційних заходів та засобів і способів правового регулювання суспільних відносин, що виникають із приводу інформаційних ресурсів [9, с. 180]. В умовах перехідного правосуддя новим об'єктом можуть бути компенсаційні та гарантійні засоби відшкодування шкоду за втрачену або незаконно поширену інформацію.

3. Удосконалення теоретичних положень щодо змісту інформаційних правовідносин. Перш за все це стосується відповідних дій, які на сучасному етапі відіграють суттєве значення. Говорячи про перехідне правосуддя, слід акцентувати увагу на тому, що інформаційні технології і масовий доступ до зв'язку здатні прискорити процес пост-конфліктного примирення, зробити його більш ефективним та допоможуть збудувати справедливіше, сильніше та витриваліше суспільство, інформуючи громадян, розширять їхні можливості (засоби масової комунікації покликані забезпечити першочергові (тимчасові) заходи із примирення) [10]. Інакше кажучи в умовах перехідного правосуддя дещо змінюється функціональна спрямованість інформаційних правовідносин, що впливає на їхній зміст, тому потрібно науково обґрунтувати такі зміни.
Висновки 3 цього дослідження. Дослідження особливостей розвитку доктрини інформаційних правовідносин в Україні в умовах політики перехідного періоду в Україні дозволяє зазначити про наступне:

1. Встановлено, що вплив перехідного правосуддя на інфрормаційні правовідносини конкретизується у наступному: трансформація інформаційного законодавства (обумовлює необхідність перегляду об'єктного та суб'єктного складу інформаційних правовідносин); компетенційно-юрисдикційні зміни (виникнення нових напрямків діяльності органів влади та місцевого самоврядування); зміни у розумінні змісту інфрормаційних правовідносин (розширення кола юридичних фрактів, за наявності яких виникають, змінюються та припиняються інформаційні правовідносини); оновлення методології правового регулювання інформаційних правовідносин; переосмислення засад регулювання інформаційної сфрери.

2. Обгрунтовано наступні перспективні напрямки розвитку доктрини інформаційних правовідносин в умовах перехідного правосуддя: узагальнення уявлень про систему суб'єктів інформаційних правовідносин (чітке розмежування обсягу та особливостей правового статусу); розвиток теорії об'єктів інфрормаційних правовідносин (детальне наукове осмислення нових об'єктів, виникнення яких зумовлено інформатизацією суспільства); удосконалення теоретичних положень щодо змісту інформаційних правовідносин (розробка наукових ідей щодо юридичних фрактів виникнення, зміни та припинення інформаційних правовідносин).

3. При цьому перспективним напрямком подальшого наукового пошуку $є$ аналіз проблеми співвідношення принципів методів та форм перехідного правосуддя із завданнями державної інформаційної політики України.

Застосування заходів адміністративної відповідальності не виключає необхідності застосування положень ст. 239 Господарського кодексу України (Господарський кодекс України) про можливість поєднання притягнення до адміністративної відповідальності юридичної особи чи фрізичної особи - суб'єкта підприємницької діяльності та застосування санкцій господарсько-правової відповідальності.

\section{БІБЛІОГРАФІЧНИЙ СПИСОК:}

1. Санья Ромайке. Правосуддя перехідного періоду в Німеччині після 1945 та 1990 років: спеціальна доповідь. Нюрнберг: Internationale Akademie Nürnberger Prinzipien. 2016. 71 c.

2. Базове дослідження із застосування правосуддя перехідного періоду в Україні: монографрія / за заг. ред. А. П. Бущенка, М. М. Гнатовського. Київ: РУМЕС. 2017. 592 с.

3. Про рішення Ради національної безпеки і оборони України від 29 грудня 2016 року «Про Доктрину інформаційної безпеки України»: Указ Президента України від 25 лютого 2017 р. № 47/2017. Урядовий кур’єр. 2017. № 48.

4. Про реформування державних і комунальних друкованих засобів масової інформації: Закон України від 24 грудня 2015 р. № 917-VIII. Голос України. 2015. № 247.

5. Про затвердження Положення про Міністерство інфрормаційної політики України: Постанова Кабінету 
Міністрів України від 14 січня 2015 р. № 2. Урядовий кур’єр. 2015. № 61.

6. Коваленко Л. П. Інформаційні правовідносини. URL: file://C:/Users/User/Downloads/62395-128225-1-SM. pdf (дата звернення: 07.10.2021).

7. Шпенов Д. Ю. Проблеми становлення та перспективи розвитку правового регулювання в інфрормаційній сфрері. Форум права. 2011. № 3. С. 894-898.

8. Марущак А. І. Поняття суб'єктів інформаційних правовідносин та їх класиффікація. Правова інфрорматика. 2006. № 4 (12). С. 44-48.

9. Сидоренко О. Інформаційні ресурси як об'єкт інформаційних правовідносин. Підприємництво, господарство і право. 2018. № 4. С. 173-182.

10. Семчинський К. В. Пост-конфрліктне примирення: інформаційно-комунікаційний вимір. URL: file:///C:/ Users/User/Downloads/3009-11024-1-PB.pdf (дата звернення: 07.10.2021).

\section{REFERENCES}

1. Sanya Romaike (2016). Transitional Justice in Germany after 1945 and 1990: Special Report. Nuremberg: International Academy Nuremberg Principles. $71 \mathrm{p}$.

2. Bushchenko, A. P., Gnatovsky M. M. ed. (2017). Basic research on the application of transitional justice in Ukraine: a monograph. Kyiv. (in Ukrainian).

3. On the decision of the National Security and Defense Council of Ukraine of December 29, 2016 «On the Doctrine of Information Security of Ukraine»: Decree of the President of Ukraine of February 25, 2017 № 47/2017. Government courier. № 48. (in Ukrainian).

4. On the reform of state and municipal print media: Law of Ukraine of December 24, 2015 № 917-VIII. Voice of Ukraine. № 247. (in Ukrainian).

5. On approval of the Regulation on the Ministry of Information Policy of Ukraine: Resolution of the Cabinet of Ministers of Ukraine of January 14, 2015 № 2. Government courier. № 61. (in Ukrainian).

6. Kovalenko, L. P. (2021). Information relations. URL: file:///C: /Users/User/Downloads/62395-128225-1-SM.pdf (access date: 07.10.2021). (in Ukrainian).

7. Shpenov, D. Y. (2011) Problems of formation and prospects of legal regulation in the information sphere. Law Forum. 3. 894-898. (in Ukrainian).

8. Marushchak, A. I. (2006) The concept of subjects of information relations and their classification. Legal informatics. 4 (12). 44-48. (in Ukrainian).

9. Sidorenko, O. (2018) Information resources as an object of information relations. Entrepreneurship, economy and law. № 4. Pp. 173-182. (in Ukrainian).

10. Semchinsky, K. V. (2018) Post-conflict reconciliation: information and communication dimension. URL: file://C:/Users/User/Downloads/3009-11024-1-PB.pdf (access date: 07.10.2021). (in Ukrainian). 